Ethos: Jurnal Penelitian dan Pengabdian Masyarakat, Vol 8, No.2, Juni 2020:145-153

\title{
Pendirian Koperasi Kelompok USAHa Bersama (SNaCK ) Dusun Kasihan RT 6 TAMANTIRTO KABUPATEN BANTUL D.I. YOGYAKARTA
}

\author{
${ }^{1}$ Muhammad Zakiy, ${ }^{2}$ Linda Kusumastuti Wardana, ${ }^{3}$ Rhafidilla Vebrynda \\ ${ }^{1,2,3}$ Universitas Muhammadiyah Yogayakarta \\ Email : ${ }^{2}$ lindawardana25@gmail.com
}

\begin{abstract}
This service program aims to empower and develop the potential of community, particularly the improvement of community's economy in Kasihan Village. Outcomes of the program are the formation of a Joint Business Group (KUB) in Kasihan Village RT.6, products that can be marketed to a wider area, packaging that meets the standards, attractive product branding, as well as good marketing and business management. In addition, other outcomes of this program are the initiation of Sharia cooperatives formation and the reporting results that can be disseminated and published in scientific journals/proceeding. Target of this community service is Kasihan Village community groups that already have cake and snack businesses. These partners are chosen because they have problems that can be resolved through the integration of KUB with business financing in Syariah Cooperative. The method used to make this program succeed is practical packaging and marketing discussion and also training by instructors who are experts in marketing management, plus initiating the formation of Sharia cooperatives and socialize it to the community. The steps taken include preparation and implementation stages through observation, arrangement of training materials, schedule of training time, socialization of Sharia Cooperative, general training and assistance, monitoring, and final report.
\end{abstract}

Keywords: Kasihan village, KUB Snack, Sharia cooperative

\begin{abstract}
Abstrak. Program ini bertujuan untuk memberdayakan dan mengembangkan potensi masyarakat, khususnya dalam hal pemberdayaan dan peningkatan ekonomi masyarakat di dusun Kasihan. Luaran yang dihasilkan adalah terbentuknya Kelompok Usaha Bersama (KUB) di dusun Kasihan RT.6, produk yang dapat dipasarkan ke daerah yang lebih luas, pengemasan yang memenuhi standard dan branding produk yang menarik, memasarkan serta memanajemen usahanya dengan baik. Selain itu, inisiasi pembentukan koperasi Syariah juga merupakan salah satu luaran dari program ini. Luaran lain dari program ini adalah hasil pelaporan dapat diseminarkan dan dipublikasikan dalam jurnal/proceding ilmiah. Sebagai sasaran pengabdian ini adalah kelompok masyarakat dusun Kasihan yang telah memiliki usaha kue dan snack. Mitra ini dipilih karena permasalahan yang dimiliki dapat diintegrasikan antara KUB dengan pembiayaan usaha di Koperasi Syariah. Untuk mencapai keberhasilan kegiatan ini, metode yang digunakan adalah diskusi dan pelatihan praktis pengemasan dan pemasaran oleh instruktur yang ahli dalam amanajemen pemasaran, serta menginisiasi terbentuknya koperasi dengan sosialisasi tentang Koperasi Syariah. Adapun langkah-langkah yang ditempuh meliputi tahap persiapan dan tahap pelaksanaan melalui observasi, penyiapan materi pelatihan, mengagendakan waktu pelatihan, sosialisasi Koperasi Syariah, pelatihan dan pendampingan, monitoring dan laporan akhir.
\end{abstract}

Kata kunci: Dusun Kasihan, KUB Snack, Koperasi Syariah, PKM, UMY. 


\section{Pendahuluan}

Dusun Kasihan RT 6 merupakan salah satu daerah yang berada dalam wilayah, Kecamatan Kasihan, Kelurahan Tamantirto, Kabupaten Bantul, D.I. Yogyakarta. Secara geografis, akses dusun ini tidak terlalu jauh dari pusat Kota Bantul maupun Yogyakarta. Mata pencaharian warga Dusun ini sangat bervariasi, sebagian besar kepala keluarga di dukuh ini bermata pencaharian sebagai peternak dan petani, sedangkan kaum wanitanya sebagian besar berprofesi sebagai pembuat kue/snack yang produknya dipasarkan di rumah dan pasar sekitar dusun tersebut, seperti pasar Gamping, pasar Niten dan pasar-pasar kecil di daerah sekitar dusun.

Gambaran desa yang masih terlihat tingginya budaya gotongroyong, dan masih menggunakan caracara tradisional dalam membiayai kehidupan sehari-hari, dapat dikatakan bahwa dusun ini belum banyak mengadopsi kehidupan masyarakat modern. Selain itu, di dusun ini juga terdapat peninggalan situs bersejarah yang masih dipelihara dan dilindungi oleh pemerintah Yogyakarta yaitu Sendang Kasihan yang merupakan peninggalan dari salah satu Walisonggo yaitu Sunan Kalijaga. Untuk itu, budaya tradisional masih sangat dijaga oleh masyarakat dusun tersebut.

Letak geografis yang merupakan salah satu akses menuju bandara baru yang dibangun di kabupaten Kulonprogo, dusun ini memiliki potensi yang besar dalam percepatan pembangunan infrastruktur, sehingga daerah ini memiliki economic rent (Noermawati et al., 2018). Kombinasi antara budaya tradisional dengan modern akan menjadikan keunggulan tersendiri bagi daerah Kasihan ini. Didukung oleh potensi masyarakat yang telah memiliki usaha rumahan, menjadikan perekonomian masyarakat sekitar akan lebih cepat berkembang. Akan tetapi, tingkat pendidikan masyarakat dusun Kasihan masih tergolong rendah, sehingga pengelolaan keuangan usaha dan literasi masyarakat terhadap manajemen keuangan masih rendah (Irfandi et al., 2018).

Masyarakat dusun Kasihan, terutama kaum wanita mayoritas mempunyai usaha kue/snack untuk tambahan pendapatan rumah tangga. Akan tetapi keahlian membuat kue tersebut hanya dilakukan sebagai hobby saja, sambil menunggu suami bekerja dan tidak ditekuni secara baik. Pendapat ini disimpulkan dari kunjungan yang dilakukan oleh Tim Pengabdian Masyarakat Universitas Muhammadiyah Yogyakarta (UMY), Namun, belum terdapat kelompokkelompok usaha bersama yang jika dibentuk akan meningkatkan potensi berkembangnya usaha tersebut menjadi lebih besar.

Kendala lain yang dihadapi masyarakat dusun Kasihan ini yaitu kurang memiliki akses untuk belajar dan mengembangkan jiwa berwirausaha dari para praktisi dan akademisi, sehingga usaha yang dijalankan belum maksimal. Melihat potensi yang dimiliki warga Kasihan ini, tim Pengabdian Masyarakat UMY mencoba merumuskan beberapa alternatif pemberdayaan masyarakat berupa bembentukan Kelompok Usaha Bersama (KUB), serta pemberian literasi keuangan kepada pelaku usaha agar dapat mengatur keuangan usahanya dengan baik. Sejalan dengan konsep pemberdayaan yang memberikan nilai tambah bagi masyarakat agar lebih mandiri (Widjajanti, 2011). Selain itu tim pengabdian juga melihat adanya potensi untuk menginisiasi terbentuknya sebuah koperasi syariah guna membantu pelaku usaha untuk menjalin kerjasama dan penambahan modal 
usaha jika diperlukan (Margolang, 2018).

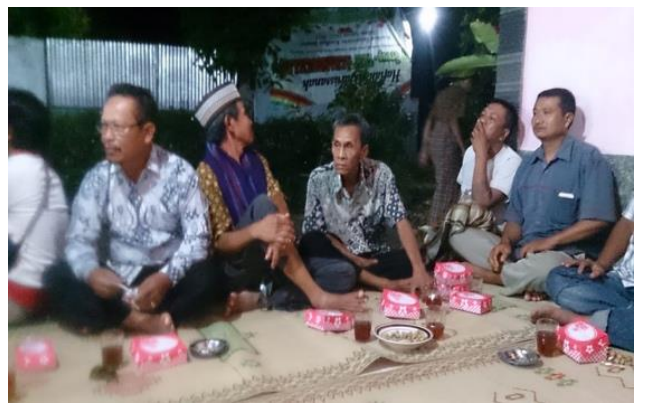

Gambar 1. Pertemuan dengan Pihak Mitra

Beberapa anggota masyarakat sudah mencoba usaha menjual kue secara perorangan dengan membuat kue/snack kecil yang dipasarkan di beberapa tempat penjualan sayur di desa, namun kurang berhasil karena potensi pembeli relatif kecil, sehingga usaha tersebut seringkali mengalami ketidak efisiensi dalam pembuatan dan sering mengalami kerugian karena harga pokok produksi lebih besar dibandingkan pendapatan yang diperoleh. Selain itu, tidak konsistennya produksi kue tersebut dibuat (diproduksi) sehingga konsumen merasa tidak pasti, membuat banyaknya sisa kue yang tidak dibeli. Dikarenakan banyaknya sisa kue yang tidak laku, maka masyarakat hanya menjadikan usaha mereka sebagai hobby saja (usaha mengisi waktun luang), bukan sebagai pendapatan utama keluarga.

Kendala lain yang dihadapi oleh masyarakat Dusun Ksihan dalam upaya mengembangkan usahanya adalah modal usaha. Pendapatan yang minim dari kepala keluarga menjadikan tidak adanya uang simpanan untuk memulai atau menambah modal usaha mereka. Masyarakat lebih memilih untuk meminjam uang ke rentenir daripada meminjam uang ke bank karena syarat dan jaminan yang ketat dan beban bunga yang tinggi. Untuk itu diperlukan pendirian sebuah Koperasi Syariah di dusun tersebut guna menyelesaikan permasalahan keuangan warga dan dapat menjadikan alternatif warga dalam hal permodalan usaha.

Pembentukan Koperasi Syariah di dusun Kasihan ini memiliki potensi yang relatif mudah. Hal ini dibuktikan dari survey tim Pengabdian dan wawancara terhadap beberapa anggota masyarakat yang telah memiliki usaha rumahan. Masyarakat juga sudah mengenal konsep simpan-pinjam, akan tetapi masih dalam bentuk riba yang merugikan salah satu pihak. Selain itu, peminjaman yang dilakukan juga masih banyak yang dihabiskan untuk barangbarang konsumtif dan jarang dilakukan untuk penambahan modal usaha.

Berdasarkan observasi awal dan diskusi yang dilakukan tim pengembangan masyarakat dengan Bapak Nardi ketua RT 06 dan beberapa tokoh masyarakat dusun Kasihan, terdapat beberapa permasalahan yang akan dipecahkan dan dicari solusinya. Adapun permasalahannya sebagai berikut:

a. Permasalahan yang dihadapi pengusaha kue dan snack dalam mengembangkan usahanya adalah:

1. Kurangnya pengetahuan mereka dalam manajemen bisnis yang baik terutama manajemen keuangan dan pemasaran.

2. Belum adanya kemasan yang layak dijual di toko-toko (belum terstandarisasi).

3. Belum adanya mitra pendanaan dalam pengembangan modal usaha

4. Belum adanya saluran penjualan yang baik

5. Belum memiliki brand sendiri dan belum adanya ijin usaha

6. Belum melakukan produksi secara masal karena saluran penjualan belum baik

7. Pola promosi yang belum efektif kepada konsumen 
8. Belum adanya pemanfaatan teknologi dalam saluran pemasaran

b. Permasalahan yang dihadapi oleh perangkat desa dalam mendirikan koperasi desa adalah:

1. Belum adanya pengetahuan mengenai mekanisme pendirian koperasi (izin serta legal formal lainnya)

2. Belum mengetahui aturan pemerintah yang mengatur mengenai koperasi

3. SDM yang ada belum memahami tugas, fungsi dan wewenang pengurus koperasi

4. Adanya tanah desa yang belum dimaksimalkan untuk pendirian kantor koperasi

5. Masyarakat belum sepenuhnya terliterasi mengenai manfaat koperasi desa

\section{Solusi dan Target Luaran}

Masalah yang dihadapi oleh pelaku usaha kue dan snack dalam akan diselesaikan dengan beberapa pendampingan, di mana kegiatan pendampingan tersebut diawali dengan:

1. Pembentukan Kelompok Usaha Bersama (KUB) agar usaha yang dijalankan bisa diintegrasikan antara satu dengan yang lainnya. Pelatihan pembuatan standart produksi yang memiliki ciri khas produk daerah setempat. Pelatihan ini akan dilaksanakan dengan memperhatikan supply chain management, yaitu mengelola dari awal (bahan mentah) sampai packaging (proses akhir yang siap dijual ke masyarakat luas).

2. Memfasilitasi dan mendampingi perihal perizinan usaha dan merek dagang untuk Kelompok Usaha Bersama (KUB).
Pendaftaran ijin akan dimulai dengan musyawarah untuk menentukan jumlah, nama dan pengurus Kelompok Usaha Bersama (KUB). Kemudian dilakukan pendampingan pengurusan ijin usaha dan merek dagang bekerjasama dengan Dinas Perindustrian dan Perdagangan DIY.

3. Melakukan pendampingan dan pelatihan standarisasi kemasan produk yang memiliki ciri khas daerah setempat. Selanjutnya, memberikan pendampingan dan pelatihan pemasaran produk dengan berbagai model penjualan langsung dan dipamerkan di beberapa tempat. Selain itu produk-produk tersebut akan dijual melalui online agar pemasarannya lebih luas dan masif.

4. Membangun media penjualan secara langsung berupa bagunan toko dengan memanfaatkan tanah desa agar dapat melakukan penjualan secara langsung.

5. Memberikan pelatihan manajemen keuangan usaha kepada mitra agar dapat mengelola keuangannya secara mandiri dan terstruktur.

a. Penyelesaian masalah dan konsep dalam mendirikan Koperasi Syariah antara lain sebagai berikut:

6. Melakukan literasi dan sosialisasi tentang manajemen keuangan dan manfaat koperasi yang melibatkan masyarakat setempat.

7. Memfasilitasi dan mendampingi proses pendirian koperasi dan mempersiapkan dokumen yang dibutuhkan untuk pendirian Koperasi Syariah. 


\section{Target Luaran}

Target luaran yang diharapkan oleh tim pengabdian untuk dihasilkan dari kegiatan pengabdian ini antara lain:

a. Terintegrasinya usaha-usaha yang dimiliki masyarakat menjadi Kelompok Usaha Bersama (KUB.

b. Kemasan dan merek dari KUB yang menarik dan berdaya saing.

c. Terbentuknya Koperasi Syariah di dusun Kasihan agar dapat menunjang perekonomian masyarakat serta mendukung pengembangan KUB yang sudah didirikan.

\section{Metode}

\section{Permasalahan Mitra 1}

a. Aspek Produksi.

Dari aspek produksi, masalah yang dihadapi Mitra 1 adalah belum memiliki standar yang memenuhi persyaratan agar dibuat KUB karena masingmasing pembuat mempunyai perpektif sendiri-sendiri, belum adanya izin usaha yang dimiliki oleh KUB, serta kemasan produk belum sesuai dengan kemasan standar produk siap jual ke pasar yang lebih luas.

b. Aspek Manajemen Usaha.

Masalah Mitra pertama adalah belum adanya pengelolaan keuangan yang baik seperti laporan keuangan usaha, serta tata kelola manajemen usaha yang belum baik. Belum ada brand dan media promosi yang dapat menentukan ciri khas dari produk tersebut.

\section{Permasalahan Mitra 2}

Mitra 2 adalah pengurus dusun Kasihan RT 6. Dari aspek manajemen usaha, Mitra 2 belum memahami fungsi koperasi syariah dan pengelolaan keuangan dalam koperasi syariah.

Mitra kedua tidak hanya membutuhkan pendampingan dan pelatihan dalam mendirikan koperasi syariah, tapi mereka juga membutuhkan ruangan sebagai kantor administrasi koperasi tersebut, lengkap dengan furniture kantor untuk memudahkan kegiatan koperasi syariah itu nantinya.

\section{Metode Pendekatan Pemecahan Masalah bagi Mitra 1}

a. Metode Pendekatan bagi Masalah Produksi Mitra 1

Kepada Mitra 1 akan diberikan pendampingan dan pelatihan pembuatan kemasan produk layak jual, promosi produk baik melalui display di toko maupun melalui online.

b. Metode Pendekatan bagi Masalah Manajemen Usaha Mitra 1

Untuk membantu Mitra 1 menata kelola manajemen usaha, tim pengabdian akan memfasilitasi dan memberikan pelatihan pengelolaan keuangan.

Dalam memasarkan produk kue dan snack yang sudah dibuat, akan dibuatkan brand beserta logo dari KUB, serta tim pengabdian akan memberikan pelatihan pemasaran kepada Mitra 1.

\section{Metode Pendekatan Pemecahan Masalah bagi Mitra 2}

Pemecahan masalah bagi Mitra kedua ini diawali dengan melakukan sosialisasi dan pelatihan bagi pengurus RT yang akan dijadikan sebagai pengurus Koperasi Syariah tentang literasi keuangan dan koperasi dengan melibatkan masyarakat desa dan bekerja sama dengan Dinas Koperasi dan UMKM DIY. 
Kemudian Mitra 2 juga difasilitasi dan diberi pendampingan dalam pendirian Koperasi Syariah, termasuk ketika mempersiapkan dokumen dan kelayakan pendirian koperasi yang bekerja sama dengan Dinas Koperasi dan UMKM DIY. Mitra 2 juga dibantu saat pendirian kantor koperasi syariah.

\section{Hasil dan Pembahasan}

\section{Persiapan Pelaksanaan Pengabdian} Sebelum melakukan kegiatan pengabdian, tim terlebih dahulu mengidentifikasi permasalahan dan kebutuhan yang diperlukan. Setelah menganalisis permasalahan dan kebutuhan, maka tim merumuskan rencana kegiatan yang tepat untuk dijalankan sesuai dengan potensi dan kebutuhan masyarakat mitra. Setelah menentukan program yang akan dijalankan, tim mendiskusikan mengenai metode pelatihan yang tepat serta mengatur jadwal kegiatan pemberdayaan antara tim pengabdi dengan masyarakat mitra agar program ini bisa berjalan secara sistematis sesuai dengan target yang diharapkan dan dapat memberikan solusi dari permasalahan yang ada.

Kegiatan pelatihan ini dimulai dengan orientasi tentang pemberdayaan, bisnis plan, komitmen dalam sebuah organisasi. Hal tersebut dilakukan untuk mendorong minat dan memperkuat komitmen anggota kelompok dalam mengikuti program. Materi pertama yang diberi bertemakan pemberdayaan masyarakat yang kesimpulannya adalah setiap individu harus berkontribusi dalam program ini agar mandiri dan dapat meningkatkan penghasilan ekonominya, selain itu kelompok ini juga didorong untuk maju dan berjalan bersama sehingga muncullah konsep pemberdayaan berbasis kelompok (KUB). Materi yang selanjutnya bertemakan bisnis plan dan komitmen, materi ini juga dimaksudkan bahwa bisnis tidak selalu menghasilkan keuntungan secara langsung didalamnya terdapat proses-proses yang harus dijalani seperti halnya produksi, distribusi dan promosi kepada calon konsumen.

\section{Pembuatan Materi dan Bahan}

Tim pengabdian membuat materi pengabdian berupa tawarantawaran dan opsi membentuk KUB. Materi-materi yang dibuat disampaikan dan ditawarkan kepada masyarakat Mitra. Selain itu, usulan nama, saluran penjualan dan promosi juga didiskusikan Bersama dengan pihak mitra. Untuk peralatan pembuatan kue dan snack sendiri menggunakan peralatan warga karena masing-masing dari warga sudah memiliki peralatan pembuat kue dan snack. Adapun peralatan yang masih kurang dan dibutuhkan oleh warga maka disediakan oleh tim pengabdian.

\section{Praktek Pelaksanaan Kegiatan Pengabdian}

Setelah melakukan koordinasi dan penjadwalan waktu pelatihan pembentukan Kelompok Usaha Bersama (KUB) antara mitra dengan tim pengabdi, selanjutnya dilakukan pelatihan pembentukan KUB. Pelatihan ini dilakukan di rumah warga yang telah memiliki usaha individu secara bergantian. Pelatihan dimulai dari mengidentifikasi kue dan snack yang sudah diproduksi oleh anggota mitra untuk dilihat kekurangan jenis kue yang dibutuhkan dalam rangka menciptakan katalog kue yang akan dijual luas.

Setelah mengetahui jumlah jenis kue dan snack yang dapat diproduksi dan kekurangannya, kemudian dicari tambahan jenis kue untuk melengkapi variasi kue yang akan dibuat paket untuk dijual. Pelatihan ini berjalan dari 
proses pemilihan bahan yang tepat, waktu yang diperlukan, kesesuaian standard produksi, kemampuan jumlah produksi sampai identifikasi saluran penjualan online maupun ofline. Selain itu, tim pengabdi juga membuka akun dalam beberapa saluran pemasaran online seperti OLX, Bukalapak, dan Bedukmutu Muhammadiyah. Harapan dari penjualan online ini dapat memperluar saluran pemasaran dan meningkatkan brand sehingga dapat meningkatkan penjualan yang lebih besar. Pemasaran merupakan suatu proses yang sangat penting dalam pengembangan sebuah usaha (Purwanti, 2012; Feriyanto, 2017).

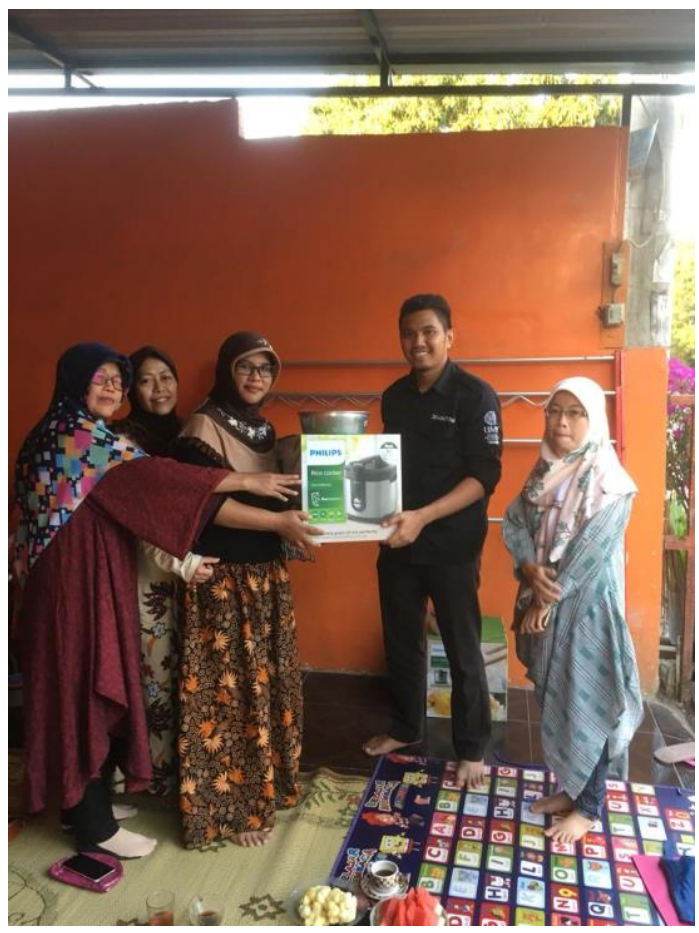

Gambar 2.

Untuk mekanisme penjualan dari mitra individu ke masyarakat luas, dilakukan cara memesan kepada anggota yang memberi harga produknya masing-masing yang kemudian akan dibeli oleh kelompok organisasi dan akan dijual oleh kelompok kepada pihak ketiga dengan harga yang lebih tinggi namun tetap rasional karena harga sebuah produk merupakan salah satu hal yang diperhatikan masyarakat (Zakiy,
2019). Harga yang diberikan hanya sebagai penutup biaya transportasi dan keuntungan yang diambil. Mekanisme yang dihasilkan dalam program ini bersifat fleksibel karena anggota dapat menjual produknya secara individu seperti sebelumnya sudah dilakukan maupun melalui KUB yang dipesan oleh pengurus berdasarkan pesananpesanan konsumen. Keuntungan yang dihasilkan disimpan dalam KUB dan digunakan untuk kepentingan KUB seperti diversifikasi produk, pelatihan pembuatan kue maupun saluran pemasaran.

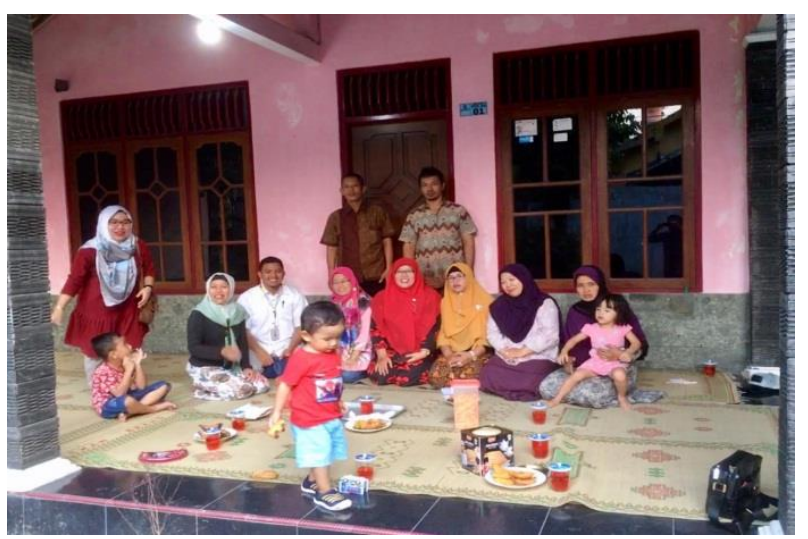

Gambar 3.

\section{Inisiasi Koperasi Syariah}

Adanya peluang untuk meningkatkan pendapatan masyarakat dengan berwirausaha di bidang kuliner, maka tim mengharapkan untuk didirikannya sebuah koperasi yang dapat menopang modal usaha warga dan melakukan simpan pinjam untuk masyarakat Kasihan dan sekitarnya. Inisiasi pendirian koperasi ini dilakukan setiap bulan dalam rapat RT yaitu pada tanggal 24 setiap bulannya. Antusias masyarakat terhadap pendirian koperasi sangat baik dan pihak RT juga sudah mengusulkan struktur pengurus Koperasi yang akan didirikan. Pelaksanaan operasional koperasi sudah dilakukan warga, terutama yang memiliki bisnis (jualan). 


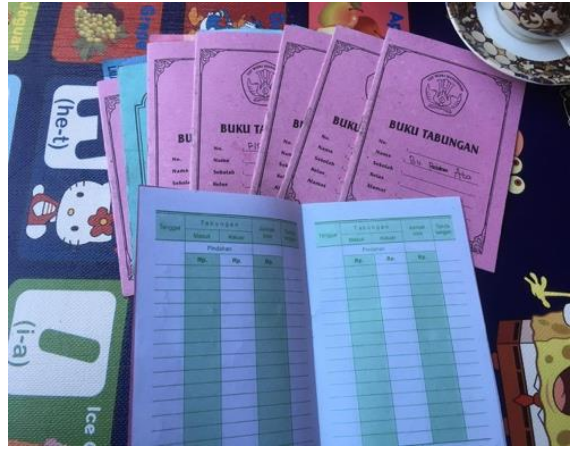

Gambar 8.

\section{Kendala yang Dihadapi}

Beberapa kendala yang dihadapi tim pengabdi baik dari internal maupun eksternal dapat dijelaskan sebagai berikut:

1. Kendala Internal

Pelatihan ini menawarkan konsep koperasi bagi setiap individu yang dulunya sudah pernah menjual produknya langsung ke pasar-pasar, sehingga tidak langsung dinikmati hasilnya oleh anggota mitra. Untuk itu, beberapa anggota mengundurkan diri dalam bergabung dengan KUB karena merasa sama seperti sebelumnya.

2. Kendala Eksternal

Kendala eksternal yang dihadapi tim pengabdi yaitu produk yang dijual harus selalu tersedia (persediaan harus selalu ada) mengingat pesanan dari konsumen yang sifatnya mendadak, sehingga tim harus menginformasikan kepada anggota mitra untuk membuat produk.

\section{Rencana Tahapan Berikutnya}

Berdasarkan hasil pencapaian dari pengabdian ini, maka kami telah merumuskan langkah-langkah yang akan dilakukan kedepannya yaitu:

1. Memfasilitasi pelatihan pemasaran produk dan pendampingan pendirian outlet kue dengan store sendiri yaitu nama KUB.

2. Melakukan pendampingan perizinan usaha ke dinas Perdagangan dan Dinas Kesehatan Propinsi DIY. organisasi

3. Mendampingi masyarakat desa mitra agar dapat mandiri secara sosial dan ekonomi.

\section{Kesimpulan dan Saran}

Rangkaian kegiatan program pengabdian masyarakat ini dapat memberikan pemahaman masyarakat akan pentingnya kerjasama tim dalam mencapai tujuan Bersama. Untuk mencapai hal ini, dibutuhkan pengorbanan dari seluruh anggota agar dapat menjaga kualitas produk yang dihasilkan sehingga dapat meningkatkan kepuasan konsumen.

Beberapa keterbatasan pelaksaan program ini yang sudah disampaikan dalam kendala yang dihadapi dalam bab sebelumnya dapat diatasi dengan mencari seseorang yang serius dalam membangun KUB sehingga dapat dilatih Manajemen pengelolaan Usaha dll.

\section{DAFTAR PUSTAKA}

Irfandi., Hidayat, T., \& Salman, R. (2018). Pemberdayaan usaha kecil menengah kuliner roti di kabupaten Simalungun. Jurnal Pengabdian kepada Masyarakat, 24(2), 661-670.

Feriyanto, N. (2017). Penentuan strategi pemasaran produk'darma karya'dengan menggunakan analisis grand matrix swot. Asian Journal of Innovation and Entrepreneurship, 2(01), 44-57.

Margolang, N. (2018). Strategi Peningkatan kelas Kemampuan Kelompok Tani. Jurnal Agro Riau, Vol. 1(3).

Noermawati, J., Pratiwi, A., Rozikan., \& Zakiy, M. (2019). Pemberdayaan 
kelompok hadroh dalam peningkatan status sosial dan ekonomi masyarakat di indonesia. In Seminar Nasional Hasil Penelitian \& Pengabdian Kepada Masyarakat (SNP2M) (pp. 399404).

Purwanti, E. (2012). Pengaruh karakteristik wirausaha, modal usaha, strategi pemasaran terhadap perkembangan UMKM di Desa Dayaan dan Kalilondo Salatiga. Jurnal Ilmiah Among Makarti, 5(9), 13 - 28.

Widjajanti, K. (2011). Model pemberdayaan masyarakat. Jurnal Ekonomi Pembangunan, 12(1), 15 27.

Zakiy, M. (2019, October). The Moderating Effect Of Switching Cost On The Influence Of Price And Service Quality Towards Switching Intention. In Third International Conference on Sustainable Innovation 2019-Humanity, Education and Social Sciences (IcoSIHESS 2019). Atlantis Press. 